\title{
Cognitive Counseling Behavioral with Modeling the Figure of Dharmawangsa to Increase Verbal
}

\author{
Ida Ayu Widya Wati ${ }^{1}$, I Ketut Suarni ${ }^{2}$, I Ketut Dharsana ${ }^{3}$ \\ ${ }^{123}$ Universitas Pendidikan Ganesha \\ e-mail:profdarsana@yahoo.com
}

Received January 22, 2017

Revised March 03, 2017

Accepted Mei 08, 2027

Published Online June 30, 2017

\section{Conflict of Interest}

\section{Disclosures:}

The authors declare that they have no significant competing financial, professional or personal interests that might have influenced the performance or presentation of the work described in this manuscript.

\begin{abstract}
This research aims to know the influence of behavioral counseling Modeling techniquesDharmawangsa figure to improve verbal through lesson study on grade XII HIGH SCHOOL Language Lab Undiksha.This type of research is Research experiment pseudo ("Quasi alphabets experiment"). The population of this research was a HIGH SCHOOL Language class XII students of the laboratory Undiksha. Sampling techniques using a purposive sampling so that the retrieved 6 students who have low verbal ability as a group of 6 persons and more experiments as a control group. The Data collected with verbal ability tests of verbal ability.Methods of analysisthe test used wasthe t-test. Results of the study indicate that there is the influence of cognitive behavioral counseling with techniques of modeling the figure against the verbal ability of Dharmawangsa through lesson study.
\end{abstract}

Keywords: the ability of verbal siswa, model of cognitive counseling , behavioral modeling techniques the figure of dharmawangsa

How to Cite: Wati, I. A. W., Suarni, I. K., \& Dharsana, I. K. (2017). Cognitive Counseling Behavioral with Modeling The Figure of Dharmawangsa to Increase Verbal. Bisma, 1(1), 1-10. https://doi.org/10.23887/128232017

\section{Introduction}

Observations of researchers against the The ability of the Verbal the students of class XII High School Language Lab Undiksha Singaraja.The interest of researchers based on symptoms: the ability to understand the ideas, the concepts expressed in words, and the ability to solve problems in words.

According to (Dharsana, 2014) verbal Ability is the ability to understand the ideas and concepts expressed in the form of words and ability to think and solve problems that are expressed in words. This definition contains the indicators are: 1) the ability to understand the ideas. 2) concept expressed in words. 3) ability to think and solve problems expressed in words (Bronwyn Morgan, Murray Maybery, 2003; Cheryl e. Sanders, David Lubinski, 1995; Cuevas, Fiore, \&Oser, 2002; Ehrenberg \& Brewer, 1993; Hasher \&Zacks, 1988; Larson et al., 1984; Näslund\& Schneider, 1991; Peter Bryant, Jane Oakhill, 2004; Susan Brady, Donald Shakweiler, 1983; THOMASWHOGABOAM and JAMESWPELLEGRINO, 1978). "Guidance can be defined as a process of granting relief to individuals who performed on an ongoing basis 
so that the individual can understand himself, so he was able to steer himself and be able to act reasonably, in accordance with the demands and the State of the environment of the school, family and society and life in General, "according to RochmanNatawidjaja (Petrus, 2002:19). The results of the observation is doneon a grade XII HIGH SCHOOL Language Lab Undiksha SingarajaNote that there are some students who experience symptomsThe ability of theVerballow assome students are less able to understand the ideas in the form of words, less able to understand concepts that are expressed in the form of words, and less able to think and solve the problems expressed in words.

Based on the foregoing, it is in the research model used counseling in this research is a model of cognitive counseling Behavioral.

In this case, the theory of the Cognitive-Behavioral Counseling is a process with procedures, steps, techniques, a skill used to enhance verbal talent run through lesson study(The Damayanti\&Aeni, 2016; Elizabeth v. Gifford, Follette, Haves, Wilson, \& Gifford, 1996; Linehan, Armstrong, Suarez, Allmon, \& Heard, 1991; Mischel, 1973; Rapee\&Heimberg, 1997).

Symptoms " verbal ability" above, shall be increased when touched and in treatment with how or techniques that are aligned with the theories of counseling. In this case, researchers using the technique of Modeling the figure of Dharmawangsa to improve verbal

According to Komalasari, dkk (2014:176) modeling is learned through observation by adding or reducing the observed behaviour, menggeneralisir a variety of observations at the same time, involve cognitive processes. There are several types of modeling: modeling the new behavior that is done through observation against the model behavior socially acceptable individuals acquire new behaviors. Modeling change behavior long by mimicking the behaviour of the model that are not accepted will strengthen/weaken social behaviour depending on the model behavior that is rewarded or punished. Symbolic modeling i.e. modeling through film and television presenting examples of behaviour, potentially as a source of model behavior. Modeling kondisioning widely used for studying emotional response (Andrew Smyth et al., 2004; Chen \& Goodman, 1996; Dinsmore, White, \& Knopf, 2002; Ersal, Fathy, Louca, Rideout, \& Stein, 2007; Mackenzie, Podsakoff, \&Podsakoff, 2011; Stephenson \&Holbert, 2003).

The purpose of this research is to find out whether there is influence of Counseling Cognitive Behavioral Modeling techniques with the figure of verbal ability against Dharmawangsa in grade XII High School Language Lab UndikshaSingaraja.

\section{Method}

The type of research used in this study is rancanaganpeneanliti "eksperimen all (Quasi alphabets experiment) " nonequivalent Design with pretest-postest control group design" this isbecause researchers do treatment (treatmen) towards a groupand performed a prestest before treatment is given. This research was conducted in the Laboratory High School UndikshaSingaraja located at JalanJatayu No.10, village Kaliuntu, Singaraja.

The population in this research is the grade XII Languages High School Lab Undiksha Singaraja totalling 35 students.

Based on the above, then in this study, sampling method used is purve portion sampling. purposive sampling is a sampling technique based on the characteristics set by the previous researcher.. As for the reason for the use of the technique of purposive sampling is done on only the data collection group of subject characteristics in accordance with the research objectives i.e. students who have the ability verbal medium and low.

Observations (Observation) is a way of collecting data by performing pengataman directly towards an object within a given period and systematically recording of certain things which are observed (Dharsana, 2015:28). The data obtained in the observation it noted in the record of observations. In this study, the researchers first perform observations against the students - students who have the ability of verbal medium and low. The advantages of using the method of observation is can be recorded simultaneously with the onset of symptoms of something; observation is a direct tool for researching various symptoms. Many aspects of human behavior that can only be observed through direct observation. Data collection 
techniques in the study was observational techniques) (observation), 2) interview techniques, verbal ability test), 3, 4) diary.

To obtain data about the Verbal Flair use multiple research instruments namely Observation Sheet 1), 2) Sheet 3) interview, diary, and 4) verbal ability test. The following this is the description of the instrument to be used in this research. In the implementation of observation, aspectsverbal abilityobserved in reference to indicators of these three aspects of theThe ability of theVerbalIE:1) the ability to understand the ideas, 2) concepts stated in words, 3 ) the ability to think and solve problems expressed in words.

\section{Result and Discussion}

The variables examined in this study is The ability of the Verbal students in class XII HIGH SCHOOL Lab Undiksha Singaraja. From initial data obtained, some students show The ability of the Verbal low as less able to understand the ideas in the form of words, less able to understand concepts that are expressed in the form of words, and less able to think and solve the problems expressed in words.

There are students who showed the symptoms of Verbal Talent that is the positive (+) and negative (-). Quantitatively, the number of students who show symptoms of Verbal Talent who has a positive (+) as much as 17 people and that shows symptoms of Verbal Talent that is negative (-) as many as 18 people. In percentage, $51 \%$ of students showed symptoms of Verbal Talent who has a positive $(+)$ and $49 \%$ of students showed symptoms of Verbal Talent which is negative (-). So, from this initial data then it can be known that students of class XII Languages more show symptoms - gejàla Verbal Talent that is positive (- ) rather than negative connotations $(+)$.

Based on the results of the observation is carried out in every model of cognitive counseling services Behavioral modeling techniques the figure of Dharmawangsa through lesson studyit is known that can happen, a decrease in symptoms the ability of the the verbalnature of the experimental group of students (-) on any of the services provided. After the execution of counseling Cognitive models service Behavioral modeling techniques Figure of Dharmawangsa, the whole experimental group students are already able to show symptoms the ability of verbalpositive $(+)$. Thus, the granting of "treatment" on the Group's experiments with models of counseling Cognitive Behavioral techniques in modeling the figure of Dharmawangsa through lesson study provide a positive influence against the ability of verbalstudents.

Qualitatively, the results of interviews conducted in the experimental group against any model of cognitive counseling services Behavioral modeling techniques the figure of Dharmawangsa through Lesson Studydecline the ability of the verbalwhich is negative (-). This shows that there is a change in the symptoms of verbal abilities of students to become more positive (+). So, in this experimental model of granting group counseling Cognitive Behavioral techniques in modeling the figure of Dharmawangsa through lesson study contribute positively towards the ability of the verbalstudents.

\section{Score Diary Individuals}

After diaries filled out by each individual students each day, then score the diary put into table score diary. In this case, the score of the diary to be used as an example is score diary a.n.NKA as follows.

Table 1 Score Student Diary a.n. NKA

\begin{tabular}{lllllll}
\hline \multicolumn{7}{c}{ TODAY } \\
\hline $\mathbf{1}$ & $\mathbf{2}$ & $\mathbf{3}$ & $\mathbf{4}$ & $\mathbf{5}$ & $\mathbf{6}$ & $\mathbf{7}$ \\
$\mathbf{3 7 . 5}$ & 40.8 & 41.8 & 44.8 & 47.8 & 49.8 & 51.3 \\
\hline
\end{tabular}


The next score student diary a.n. NKA incorporated into daily chart as follows:

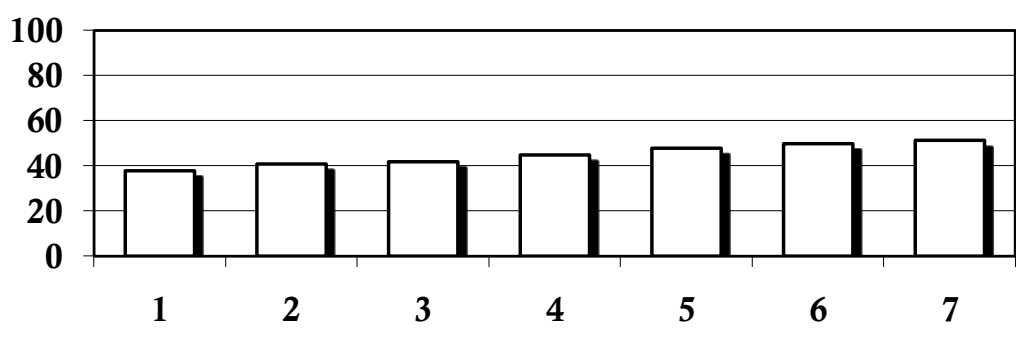

Pictures 1 Graph Student Diary a.n. NKA

After a score the student diary a.n.NKA incorporated into daily chart, then score a weekly student diary a. n NKA tabulated from his daily score. The following tabulated score a weekly student diary a.n.NKA.

Table 2 Score Diary Downloads Students a.n. NKA

\begin{tabular}{cccc}
\hline \multicolumn{3}{c}{ SUNDAY } & $\mathbf{4}$ \\
\hline $\mathbf{1}$ & $\mathbf{2}$ & $\mathbf{3}$ & 85 \\
$\mathbf{1 4 . 1}$ & 30.3 & 49.7 & \\
\hline
\end{tabular}

Next tabulate the average score of the diary weekly student created by NKA inserted in the weekly chart as follows:

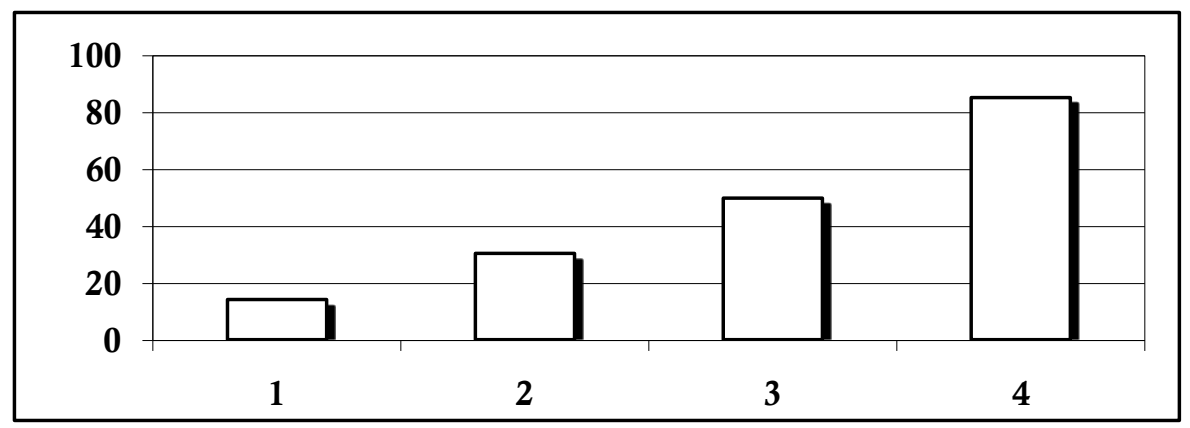

Pictures 2 Graph Weekly Diary a.n. NKA

Based on the results of the diary made by NKA it is known that, then it can happen penigkatan score diary a.n.NKA in any of the services provided. So, from this weekly diary and be aware that the implementation of the "treatment" that do contribute positively towards the ability of verbal owned by NKA.

\section{Score Diary of classical}

After each students fill out a diary, then score a diary of each individual in the insert into table score diary in class. The following is a table of student diary scores of classical. 
Table 3 Score Diary Classical

\begin{tabular}{lllllll}
\hline \multicolumn{7}{c}{ TODAY } \\
\hline $\mathbf{1}$ & $\mathbf{2}$ & $\mathbf{3}$ & $\mathbf{4}$ & $\mathbf{5}$ & $\mathbf{6}$ & $\mathbf{7}$ \\
$\mathbf{3 6 . 4 1}$ & 39.05 & 39.97 & 43.35 & 46.56 & 48.48 & 51.22 \\
& & & & & & \\
\hline
\end{tabular}

The next score student diary classical incorporated into daily chart as follows:

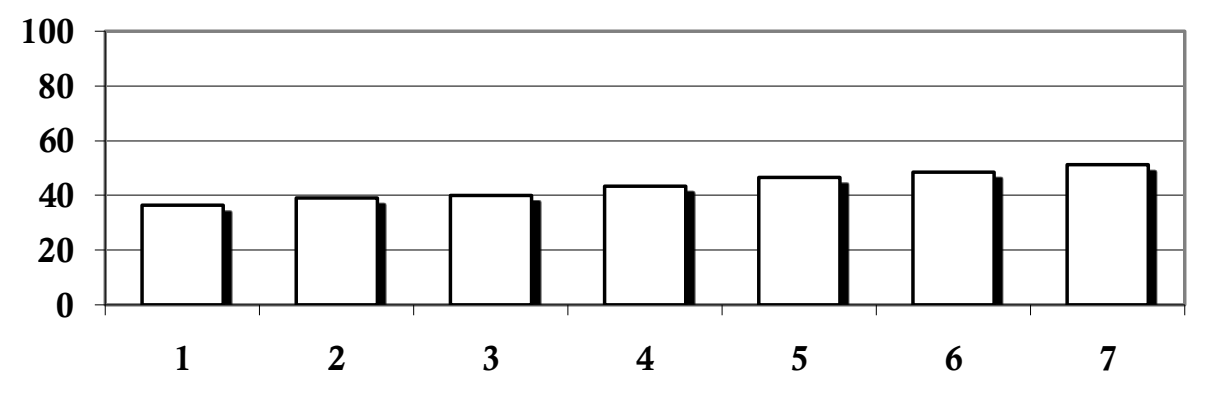

Figure 3 Diary Of Classical Charts

After the diary each students put in a daily chart, then score a weekly diary of each individual from his daily score tabulated. The following tabulated score a weekly diary of the studentsin the class.

Table 4 Score Diary Downloads Classical

\begin{tabular}{cccc}
\hline \multicolumn{5}{c}{ SUNDAY } & $\mathbf{4}$ \\
\hline $\mathbf{1}$ & 2 & 3 & 80.38 \\
$\mathbf{1 2 . 8 6}$ & 29.71 & 50.75 & \\
\hline
\end{tabular}

Next tabulate the average score of the diary weekly students entered into the weekly charts:

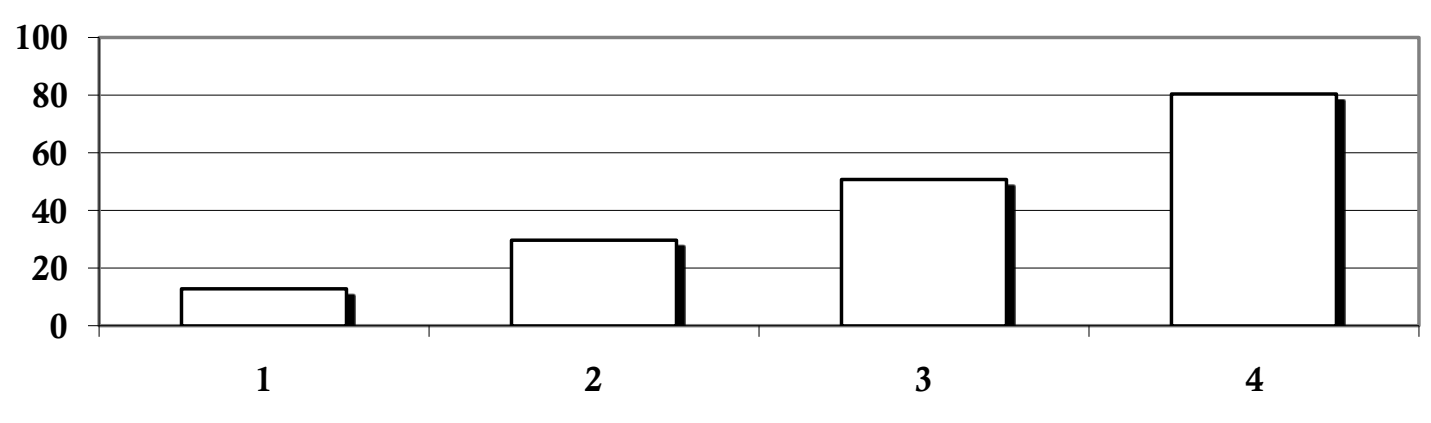

Figure 4 Graph Weekly Diary Classical

Based on the results of the book an $\mathrm{n}$, then it can be known that happen peningkatan score student diary in each service model of counseling Cognitive Behavioral techniques in modeling the figure of Dharmawangsa . So, from this weekly diary and be aware that the execution of counseling model of cognitive Behavioral techniques in modeling the figure of Dharmawangsa contribute positively towards the ability of the verbal students. 
Based on the results of the analysis of pretest 12 students who have low verbal ability showed an increase in scores from pretest to posttest.

Statistical tests of normality is carried out using statistical tests -Kolmogrovsmirnovwith the help of the program SPSS 16.0 for Windows-PC. Testing is done on the unit of analysis that is comprised of a group of experimental and control group.

Data distribution normality test aims to determine the normality of the data distribution capabilities of the verbal. The data is said to be normal if distributed significant value obtained is greater than $\alpha(0.05)$.

Based on the results of the analysis that was done then it can be inferred that if the value of Kolmogorov-SmimovZ obtained of 0.607 is greater than 0.05 significance of experimental group then the data is Gaussian.

Based on the results of the t-test Test in table 4.12 shows the value tcalculate $=3.411$ with significance of 0.01 . Then it can be stated that Ho is rejected, and the $\mathrm{Ha}$ is received. So be aware that there is the influence of cognitive behavioral counseling with techniques of modeling the figure of Dharmawangsa to improve verbal through lesson study.

To find out how the influence of cognitive-behavioral counseling with techniques of modeling the figure of Dharmawangsa to improve verbal students will be sought using the formula Efeeck.

$$
\begin{aligned}
& E S=t \sqrt{\frac{1}{n}} \\
& E S=3,411 \sqrt{\frac{1}{6}} \\
& E S=1
\end{aligned}
$$

Based on the value of ICE = 1 then the ICE is at a high category, so it can be stated that the cognitive behavioral Counseling with techniques of modeling the figure of high influence after Dharmawangsa's treatment of the Verbal Abilities of students.

Data obtained from the results of the data collection form verbal ability test previouslyobtained samples as many as 12 students who have verbal ability low, then the sample was formed into two groups, group 1 as a group of 6 alphabets experiment people students are given counselling by using counselling approach cognitive behavioral techniques modeling the figure of Dharmawangsa and 2 as a control group of 6 people students.

In a study need to be described or explained the process of counseling that was implemented to be able to give you an idea of the research process was implemented the following explanation and description implementation of counseling cognitive behavioral techniques modeling the figure of Dharmawangsa to improve verbal.

Discussion of the research results are presented in this section are the results of the descriptive analysis.

\section{There is significant influence implementation of cognitive behavioral counseling technique of modeling} the figure of Dharmawangsa Verbal Ability against students

The theory of cognitive behavioral counseling isa process with procedures, steps, techniques, skills that are used to enhance the ability of the verbal run through lesson study. 
In this study, the technique used to verbal ability students, namely modeling the figure of Dharmawangsa. modeling is one of the counseling technique wherein one learns to make and implement new behavior through the process of observation, observing the behavior of others, menggeneralisir (model), where in this process also involves modeling cognitive and creative instead of merely imitating/imitation only. Modeling is a consequence of behaviour mimics the others from experience either direct or

indirect experience, so the emotional reactions and the fear of someone can be eliminated. The Modeling technique is used to provide the model to konseli so that konseli can imitate the given model and can improve verbal students.

Counselling Approach cognitive behavioral and engineering modeling the figure of Dharmawangsa used in the process of counselling together with students who are zoned to have verbal ability low, the Group was formed and the execution of counseling done to know the influence that happens to individuals who have verbal ability low. Verbal Ability very important in the individual because it has the ability of verbal high individual able to develop optimally then, held counseling cognitive behavioral techniques with the modeling of the figure of Dharmawangsa.

Counseling cognitive behavioralthe goal of cognitive behavioral counseling is to help konseli solving present but not forgetting his past with irrational thoughts change into rational so that can eventually affect retrieval the negative into positive action by aligning think, feel and act.

Empirical Findings of this research there are States that are obtained by using the (t-test) the value tcalculate $=3.411$ with the significance of 0.01 . Then it can thus be concluded that $\mathrm{H} 0$ is rejected and the $\mathrm{Ha}$ are received. So be aware that there is the influence of cognitive behavioral counseling with techniques of modeling the figure of Dharmawangsa to improve verbal through lesson study.

\section{Conclusion}

From the research that has been done, it can be concludedthat there is the influence of counselling cognitive behavioral techniques modeling the figure of Dharmawangsa to improve verbal through lesson study on grade XII HIGH SCHOOL Language Lab Undiksha Singaraja. Based on the hypothesis test results in the table above was obtained by test t-Test shows the value tcalculate $=3.411$ with significance of 0.01. Then it can be stated that Ho is rejected, and the Ha is received. So be aware that there is the influence of cognitive behavioral counseling with techniques of modeling the figure of Dharmawangsa to improve verbal through lesson study.

\section{References}

Dantes, Nyoman. (2012). Metode Penelitian. Yogyakarta : CV Andi Offset.

Dharsana, Ketut. (2013). Modul Teori-Teori Konseling. Singaraja: Jurusan Bimbingan Konseling, FIP UNDIKSHA

Dharsana, Ketut. (2014). Teori-Teori Konseling dan Teknik Konseling. Singaraja: BK FIP Undiksha.

Dharsana, Ketut. (2015). RPBK Seri 1 Bimbingan Klasikal, Bimbingan Kelompok,KonselingKelompok, Konseling Individu Untuk Pengembangan Variabel Terikat Bakat Verbal. Singaraja: BK FIP Undiksha.

Komalasari, dkk. (2014). Teori dan Teknik Konseling. Jakarta : PT Indeks

Sukardi, Dewa Ketu t\& Desak P.E. Nila Kusmawati. (2009). Analisis Tes Psikologis Teori dan Praktik. Jakarta: PT RinekaCipta 
Andrew Smyth, by W., Masri, S. F., Kosmatopoulos, E. B., Chassiakos, A. G., Caughey, T. K., \& Hysteretic, A. I. (2004). Development of Adaptive Modeling Techniques for Nonlinear Hysteretic Systems. International Journal of Nonlinear Mechanics International Journal of Non-Linear Mechanics, 21(8), 1435-1451. https://doi.org/10.1016/S0020-7462(02)00031-8

Bronwyn Morgan, Murray Maybery, and K. D. (2003). Weak Central Coherence, Poor Joint Attention, and Low Verbal Ability: Independent Deficits in Early Autism. Developmental Psychology, 39. Retrieved from

https://www.researchgate.net/publication/10663388_Weak_Central_Coherence_Poor_Joint_Atten tion_and_Low_Verbal_Ability_Independent_Deficits_in_Early_Autism

Chen, S. F., \& Goodman, J. (1996). An Empirical Study of Smoothing Techniques for Language Modeling. Retrieved from https://arxiv.org/pdf/cmp-lg/9606011.pdf

Cheryl E. Sanders, David Lubinski, and C. P. B. (1995). Does the Defining Issues Test Measure Psychologic Phenomena Distinct From Verbal Ability?: An Examination of Lykken's Query, 69, 498-504. Retrieved from

https://www.researchgate.net/profile/David_Lubinski/publication/232563257_Does_the_Definin g_Issues_Test_Measure_Psychological_Phenomena_Distinct_From_Verbal_Ability_An_Examinati on_of_Lykken's_Query/links/548feb360cf225bf66a806db/Does-the-Defining-Issues-T

Cuevas, H. M., Fiore, S. M., \& Oser, R. L. (2002). Scaffolding cognitive and metacognitive processes in low verbal ability learners: Use of diagrams in computer-based training environments. Instructional Science, 30 , 433-464. Retrieved from http://www.speakeasydesigns.com/SDSU/student/SAGE/compsprep/Diagrams_in_CBT.pdf

Damayanti, R., \& Aeni, T. (2016). Efektivitas Konseling Behavioral dengan Teknik Modeling untuk mengatasi Perilaku Agresif pada Peserta Didik Kelas VIII B SMP Negeri 07 Bandar Lampung. Konseli: Jurnal Bimbingan Dan Konseling (E-Journal), 3(1), 1-10. Retrieved from http://ejournal.radenintan.ac.id/index.php/konseli/article/view/572

Dinsmore, S. J., White, G. C., \& Knopf, F. L. (2002). Advanced Techniques for Modeling Avian Nest Survival. Ecology, 83(12), 3476-3488. Retrieved from http://links.jstor.org/sici?sici=00129658\%28200212\%2983\%3A12\%3C3476\%3AATFMAN\%3E2.0.CO\%3B2-P

Ehrenberg, R. G., \& Brewer, D. J. (1993). Did Teachers' Race and Verbal Ability Matter in the 1960's? Coleman Revisited. Retrieved from http://digitalcommons.ilr.cornell.edu/articles

Elizabeth V Gifford, K. S., Follette, V. M., Haves, S. C., Wilson, K. G., \& Gifford, E. V. (1996). Experiential Avoidance and Behavioral Disorders: A Functional Dimensional Approach to Diagnosis and Treatment. Journal of Consulting and Clinical Psychology Copyright, 64(6), 1152-1168. Retrieved from https://thehappinesstrap.com/upimages/experiential_avoidance.pdf

Ersal, T., Fathy, H. K., Louca, L. S., Rideout, D. G., \& Stein, J. L. (2007). A Review of Proper Modeling Techniques. Retrieved from http://www-personal.umich.edu/ tersal/papers/paper5.pdf

Hasher, L., \& Zacks, R. T. (1988). Working Memory, Comprehension, and Aging: A Review and a New View. Psychology of Learning and Motivation - Advances in Research and Theory. https://doi.org/10.1016/S0079-7421(08)60041-9

Larson, C. O., Dansereau, D. F., O 'donnell, A., Hythecker, V., Lambiotte, J. G., \& Rocklin, T. R. (1984). Verbal Ability and Cooperative Learning: Transfer of Effects. Journal of Reading Behavior, XVI(4). Retrieved from http://journals.sagepub.com/doi/pdf/10.1080/10862968409547522 
Linehan, M. M., Armstrong, H. E., Suarez, A., Allmon, D., \& Heard, H. L. (1991). Cognitive-Behavioral Treatment of Chronically Parasuicidal Borderline Patients. Archives of General Psychiatry, 48(12), 1060. https://doi.org/10.1001/archpsyc. 1991.01810360024003

Mackenzie, S. B., Podsakoff, P. M., \& Podsakoff, N. P. (2011). Construct Measurement and Validation Procedures in Mis and Behavioral Research: Integrating New And Existing Techniques. MIS Quarterly, 35(2), 293-334. Retrieved from https://temme.wiwi.uni-

wuppertal.de/fileadmin/_migrated/content_uploads/mackenzie_podsakoff_podsakoff_2011_01.pdf

Mischel, J. W. (1973). Toward a Cognitive Social Learning Reconceptualization of Personality. Psychological Review, 80(4), 252-283. Retrieved from http://psych.colorado.edu/ carey/Courses/PSYC5112/Readings/psnSituation_Mischel01.pdf

Näslund, J. C., \& Schneider, W. (1991). Longitudinal Effects of Verbal Ability, Memory Capacity, and Phonological Awareness on Reading Performance. Europeon Journal of Psychology of Educalion, 4, 375392. Retrieved from https://opus.bibliothek.uni-wuerzburg.de/opus4wuerzburg/frontdoor/deliver/index/docId/7204/file/Schneider_W_OPUS_7204.pdf

Peter Bryant, Jane Oakhill, K. C. (2004). Children's Reading Comprehension Ability: Concurrent Prediction by Working Memory, Verbal Ability, and Component Skil. Journal of Educational Psychology, 96.

Retrieved from

https://www.researchgate.net/profile/Kate_Cain/publication/228727270_Children's_Reading_Co mprehension_Ability_Concurrent_Prediction_by_Working_Memory_Verbal_Ability_and_Compon ent_Skills/links/09e4150a2c93bb8ad4000000.pdf

Rapee, R. M., \& Heimberg, R. G. (1997). A Cognitive-Behavioral Model of Anxiety in Social Phobia. Behav. Res. Ther, 35(8), 741-756. Retrieved from https://pdfs.semanticscholar.org/b340/9ea9e4d68c1f37d408ceb27be3656d43c57e.pdf

Stephenson, M. T., \& Holbert, R. L. (2003). A Monte Carlo Simulation of Observable Versus Latent Variable Structural Equation Modeling Techniques. https://doi.org/10.1177/0093650203252410

Susan Brady, Donald Shakweiler, V. M. (1983). Speech Perception and Memory Coding In Relation to Reading Ability. Journal of Experimental Child Psychologi, 35, 345-367. Retrieved from http://www.haskins.yale.edu/Reprints/HL0405.pdf

Thomaswhogaboam and Jameswpellegrino. (1978). Hunting for individual differences in cognitive processes: Verbal ability and semantic processing of pictures and words. Memory \& Cognition, 6(2), 189-193. https://doi.org/10.3758/BF03197445 
Conflict of Interest Disclosures:

The authors declare that they have no significant competing financial, professional or personal interests that might have influenced the performance or presentation of the work described in this manuscript.

Copyrights Holder: Ida Ayu Widya Wati, I Ketut Suarni, I Ketut Dharsana 2017

First Publication Right: BISMA The Journal of Counseling

https://doi.org/10.23887/128232017

Open Access Article | CC-BY Creative Commons Attribution 4.0 International License.

Word Count: 